\title{
In Memoriam: R. Douglas Cope (1955-2019)
}

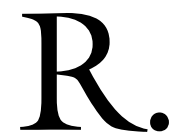

Douglas Cope, Associate Professor of History at Brown University, died on October 6, 2019, at Rhode Island Hospital. He was 64 years old. Doug was the author of the influential 1994 book, The Limits of Racial Domination: Plebeian Society in Colonial Mexico City, 1660-1720 (University of Wisconsin Press), and a legendary teacher at Brown for over 30 years.

Growing up in a working-class family in Port Huron, Michigan, Doug earned an associate's degree in Humanities from the St. Clair County Community College in 1977, and a BA in History from Oakland University in Rochester, Michigan, in 1979. He went to the University of Wisconsin-Madison for his $\mathrm{PhD}$, where he worked with Thomas Skidmore, Florencia Mallon and Steve J. Stern. At Wisconsin, Doug was part of an influential cohort of social historians of Latin America who channeled leftist political commitments into rigorous and innovative research strategies. His dissertation, which he began as a Fulbright Scholar in Mexico City, formed the first stage of a lifelong, deeply personal engagement with the history of the poor and working classes in colonial Mexico City. He earned his $\mathrm{PhD}$ in 1987 and published The Limits of Racial Domination in 1994.

The Limits of Racial Domination investigated the relationship between race and class in mid-colonial Mexico City, through the lived experience of so-called casta identities: negro, mulato, mestizo, zambo, and others. New Spain was a center for race ideology in the Hispanic world. Although the baroque system of racial subcategories catalogued in Mexican casta paintings was largely imaginary, the law imposed real and often punitive distinctions between indigenous, mestizo, African-descendant, and Spanish populations. Previous scholars assumed that most people accepted and internalized these identity labels. Through a variety of imaginative archival strategies, Doug uncovered evidence of ordinary people challenging them, switching between them, and marrying or socializing across them. In Steve J. Stern's words, "He sensed, probably because of his own keen sensitivity to social class dynamics, that the casta system might end up being more a reflection of elite sensibilities than 
on-the-ground realities of social life. And he was determined to understand plebeian life on its own terms." It may be that growing up in Michigan between the 1962 Port Huron Statement and the 1967 Detroit riots, when racial strife exploded the dream of working-class solidarity in America's industrial capital, helped shape his perspective: casta was a false consciousness, projected by colonial elites to divide and dominate the plebeian majority. Its failure as a hegemonic ideology helped explain the later phenomenon of mass mestizaje in Mexican history, and it was an emancipatory counterexample to twentieth-century North America.

Doug's book received honorable mention for the 1995 Herbert E. Bolton Prize for the year's best book in Latin American history. After a quarter century, during which race (or "race") has dominated the agenda of colonial historiography, the book remains relevant, holding its place on undergraduate and graduate reading lists. This is due to its vigorous, jargon-free prose, clear framing of issues, and a series of discrete research inquiries (for example, his tabulation of personal names as evidence of identity-claiming) that are useful for teaching.

Following brief stints at the University of Oregon and the University of Miami, Doug came to Brown in 1988. He became known as a gifted teacher and charismatic lecturer, receiving Brown's William G. McLoughlin Award for Excellence in Teaching. Doug expanded colonial Latin American history into a two-semester sequence, half of which focused on social history and half on Atlantic World imperial politics. He also created courses on the Mexican Revolution, modern Mexico, Maya peoples, invasion and conquest, and-a few years ago- a new course on early modern pirates, which became one of his most popular. He lectured with confidence and fluency, filling his presentations with stories and unexpected piquant details. More than one of his undergraduate students ended up a professional historian, including Leo J. Garofalo (Professor, Connecticut College; Brown class of 1992), who recalls: "He showed all of us that history was fun, that it mattered, and that it was rewarding, hard work." Without PowerPoint or videos, Doug kept undergraduates attentive and engaged until the last year of his life, in his final years lecturing from his wheelchair.

Doug invested much of his time in advising, both individually and through overseeing groups of undergraduate senior thesis writers. He did not advise many dissertations, but tutored generations of graduate students whose main field was modern Latin America or colonial North America in colonial Latin American history, and taught graduate seminars on the Atlantic World and other topics. These relationships were among his most important. Graduate student Javier Fernández-Galeano calls Doug a "moral compass," and adds: "As someone who came from a humble background he was always invested in 
making everyone feel included. That kind of presence is something very unique in academia." Another graduate student, Diego Luis, remembers: "In his soft-spoken manner, he pushed us to ask the biggest possible questions about colonial Latin American history.”

Doug published dozens of book reviews-in the American Historical Review, the Latin American Research Review, The Americas, Ethnohistory, The Historian, and other journals-and served a five-year term as book review editor for the Hispanic American Historical Review. He seemed to read everything that was published in his field, constantly updating syllabi and reading lists with new publications. The books that filled every shelf and surface, as well as tall, precarious piles on the floor, seemed to threaten to burst out his office door and walls.

He worked for many years on a second book on the informal economy in eighteenth-century Mexico City, but never finished it, in part because poor health made research travel difficult, and perhaps in part because of his lifelong perfectionism. Steve J. Stern recalls affectionately that he and Tom Skidmore schemed to have Tom show up unexpectedly at Doug's graduate-student apartment, to convince him to turn over draft dissertation chapters. Later in life, there was no one to play that role.

Doug was a deeply solitary man. Whether with new acquaintances or colleagues of many years, he was friendly, courteous, and distant. He lived austerely, buying few things and giving a large part of his income to charities. His only extravagance was in the gifts he gave to his nieces and nephews, to whom he was close. He loved baseball, an enthusiasm that dated back to family trips to Tiger Stadium in Detroit when he was a boy. One of his few non-professional activities was a fantasy baseball league organized by Brown colleagues and students; for years he traveled to Philadelphia for the annual league draft. Doug's health, however, was never good. Most serious was the diabetes that took one of his feet, left him in a wheelchair in his last years, and led to his early death.

The Brown History Department has established the R. Douglas Cope Memorial Undergraduate Fund in his honor, to recognize outstanding low-income and first-generation history concentrators. Anyone who wants to contribute to this fund may send a check payable to the Brown University History Department (memo line: Cope Prize), to Brown University, Department of History, c/o Cherrie Guerzon, Box N, 79 Brown Street, Providence, RI 02912. 